\title{
Společenská dimenze českého motorismu
}

\author{
IVAN JAKUBEC*
}

Czech Automobile Sector in a Social Context

\begin{abstract}
The aim of this study is to review already conducted research focusing on historical development of Czech automotive industry. Keeping interdisciplinary interests in focus, the automotive industry as a social phenomenon such as a symbol of leisure time, or as a symbol of cultural inspiration is studied as well as a mode of transport and a technical product. The study reveals that social context of automotive sector is rather marginalized in existing research material and deserve deeper scientific attention.
\end{abstract}

Keywords: automotive; Czech society of 20th century

DOI: $10.14712 / 23363525.2018 .54$

Když Karl Benz a Gottlieb Daimler sestavili v 80. letech 19. století první spalovacím motorem poháněný automobil, tak si jistě neuvědomovali, jak dalekosáhlé dopady bude mít jejich vynález na všechny sféry lidského života. Jen stěží bychom našli oblast lidského života, kterou motorismus neovlivnil. V průběhu svého prvního století automobil doprovází člověka od kolébky až po hrob, přináší mu mnoho slastných i strastných chvil ve všedním i svátečním životě. Opticky i reálně zkrátil vzdálenosti, nebot desítky kilometrů, které představovaly v „předautomobilové“ době celodenní namáhavou cestu, se za volantem automobilu proměnily $\mathrm{v}$ pouhé desítky minut celkem př́ijemného posezení nevyžadujícího žádnou podstatnější fyzickou námahu. Nejde však jen o život člověka. Motorismus změnil tvář krajiny i měst. Novodobou (automobilovou) krajinu protkala hustá sít silnic se zpevněným povrchem, která povaze automobilu nejvíce vyhovuje, automobil si řekl i o své vlastní dálkové silnice (dálnice), jež jsou jen jeho výsostnou državou. Města se též proměnila k nepoznání, městské ulice lemují tisíce odpočívajících motorových ořů, ve vteřině připravených k použití. Architekturu automobil obohatil o nový typ stavby - garáž, která doplnila, či spíše nahradila dřivější konírny, a městský intravilán rozšířil o parkoviště. Bylo by možné pokračovat ve výčtu rovin společnosti, kultury, hospodářství, ale i politiky domácí i mezinárodní, které automobil, pokud ne přímo utvářel, tak alespoň ovlivňoval.

Je však až s podivem, že dosud v české historické literatuře bylo motorismu a jeho širokým souvislostem věnováno jen tak málo prostoru a řada témat nepřilákala dosud pozornost vůbec. Cílem tohoto textu je nastínit současný stav zpracování motorismu v české historiografii a současně poukázat na nezpracovaná místa a formulovat otázky, kterým

Prof. PhDr. Ivan Jakubec, CSc., Ústav hospodářských a sociálních dějin, Filozofická fakulta, Univerzita Karlova, Celetná 20, 11642 Praha 1. E-mail: ivan.jakubec@ff.cuni.cz. Autor děkuje doc. JUDr. PhDr. Janu Štemberkovi, Ph.D., za podněty a připomínky. Vydáno za finanční podpory Ministerstva kultury ČR v rámci projektu NAKI II České století motorismu (DG18P02OVV051), který v letech 2018-2022 realizují Fakulta humanitních studií Univerzity Karlovy, Národní technické muzeum a Technické muzeum v Brně. 
by se měl další výzkum při hledání odpovědí vydat. Právě na dosud opomíjená témata se chtějí zaměrit realizátoři zpracovávaného projektu, nebot̉ není pochyb, že od 20. století patři motorové vozidlo $\mathrm{k}$ české kulturní identitě.

$\mathrm{V}$ rámci zkoumání hospodářských dějin a dějin techniky byla věnována pozornost automobilovému průmyslu, který má $\mathrm{v}$ českém prostředí více než stodvacetiletou tradici. Je zřejmé, že $\mathrm{v}$ př́istupu $\mathrm{k}$ automobilovému průmyslu převažuje prŕstup technický. ${ }^{1}$ Poněkud více do kontextu dějin techniky a širších souvislostí je zasazena automobilová výroba v kolektivní práci vzniklé na půdě Národního technického muzea Studie o technice $v$ českých zemích. ${ }^{2}$ Katalog přehledových prací o technickém vývoji automobilů doplňují monografie, tematicky zaměřené na jednotlivé automobilové značky. V nedávné době se tak celkem systematicky podařilo zpracovat historii nejvýznamnějších automobilových výrobců s důrazem na meziválečné období. ${ }^{3}$ Vedle automobilových výrobců byla pozornost věnována i karosárnám. ${ }^{4}$

Z pohledu hospodářských dějin je ještě důležitý pohled na automobilismus jako na odvětví dopravy. Pozornost automobilismu byla věnována v širším kontextu dopravního trhu meziválečného Československa. ${ }^{5} \mathrm{~V}$ následujícím období válečných let byla doprava sledována spíše se zaměřením na Slovensko. ${ }^{6}$ Další oblastí, která se dočkala svého zpracování, byla automobilová doprava z pohledu podnikatelského zájmu soukromého i státního. ${ }^{7}$ Podrobněji je rozpracovaná i problematika státní autobusové dopravy, avšak spíše

1 Kuba, Adolf [1986]. Automobil v srdci Evropy. Praha: NADAS; týž [1988]. Atlas našich automobilů 1. Praha: NADAS; týž [1988]. Atlas našich automobilů 2. Praha: NADAS; Kuba, Adolf - Spremo, Milan [1989]. Atlas našich automobilů 3. Praha: NADAS; Král, Zdeněk [2010]. Století českého automobilu. Praha: BB/art; Cendrych, Mario René - Nachtmann, Lukáš [2007]. Škoda - auta známá i neznámá: prototypy i sériové automobily vyráběné od roku 1932: kompletní a dosud nepublikovaný přehled produkce od začátku výroby 1905, včetně nákladních automobilü: doplněno o prototypy 60. a 80. let. 2., upr. vyd. Praha: Grada.

2 Studie o technice v českých zemích 1800-1918, 1918-1945, 1945-1992 [1983-2003]. 9 sv. Praha: NTM, Encyklopedický dům.

3 Z řady dílčích prací lze uvést např. Gomola, Miroslav [1998]. Automobily Tatra. Luxusní vozy z Kopřivnice (1920-1940). Brno: AGM CZ; Kožíšek, Petr - Králík, Jan [2003]. L\&K, Škoda, díl 1. Cesta vzhưru (1895-1945). Týnec nad Sázavou: Moto Public; Procházka, Hubert - Martof, Jan [2009]. Automobily Aero, Jawa, Walter, Wikov, „Z“(1905-1946). Brno: Computer Press.

4 Černý, Jan [2007]. Automobily Tatra s karoseriemi Sodomka. Vysoké Mýto; týž [2008]. Automobily Aero s karoseriemi Sodomka. Vysoké Mýto: Regionální muzeum; Černý Jan - Štěpán, Martin [2009]. Automobily Praga s karoseriemi Sodomka. Vysoké Mýto: Regionální muzeum; Králík, Jan [2008]. Karoserie Petera. Brno: Atelier Kupka.

5 Jakubec, Ivan - Štemberk, Jan [2017]. „Vůz rozbit, kůň zabit, kočí zůstal bez pohromy.“ Dopravní neštěstí jako součást lidského života. In. Hrdina, Martin - Bendová, Eva - Piorecká, Kateřina (ed.): Člověk a společnost 19. století tváři v tvář katastrofě: sborník př́spěvků z 36. ročníku mezioborového sympozia $k$ problematice 19. století. Plzeň, 25.-27. února 2016. Praha: Academia, s. 107-121; Jakubec, Ivan [2008]. Výrobna automobilů jako výrobna rychlosti. Firma Laurin and Klement v Mladé Boleslavi. In. Blümlová, Dagmar, a kol.: Čas rychlých kol a kř́del, aneb Mezi Laurinem a Kašparem: kapitoly z kulturních dějin přelomu 19. a 20. století. České Budějovice: JČU, Historia culturae 14, Studia 9, s. 148-181; týž [1991]. Vývoj československých a německých drah 1929-1937. Praha: Karolinum. Acta Universitatis Carolinae. Philosophica et historica. Monographia $139 / 1991$.

6 Sabol, Miroslav [2014]. Limity a hranice cestnej dopravy v 40. rokoch 20, storočia na Slovensku. Historický časopis 62 (3): 471-499; týž [2015]. Dejiny dopravy na Slovensku 1938-1948 (1950), jej hranice a limity. Bratislava: Veda.

7 Štemberk, Jan [2010]. Podnikání v automobilové dopravě v českých zemích v první polovině 20. století, Acta Universitatis Carolinae, Philosophica et Historica - Monographia CLXV/2007. Praha: Karolinum. 
v popisném podání. ${ }^{8} \mathrm{Z}$ pohledu úlohy automobilu (autobusu) v městské dopravě je možné poukázat na řadu prací Pavla Fojtíka. ${ }^{9}$

Nelze opominout ani oblast služeb a obchodu. Automobil se stal samozřejmě zbožím, které bylo nutné uplatnit na trhu. Pro meziválečné období se nám zachoval ojedinělý pramen pamětí prodavače automobilů. ${ }^{10}$ Také reklama tak nemohla zůstat stranou. Analýza způsobů a forem komunikace se zákazníky, jež se nevytratila ani v socialistickém období vývoje, též nebyla v českém prostředí dosud provedena. K dispozici máme práci české autorky, vydanou v Německu, která se věnovala reklamě a reklamním postupům firmy AUDI při propagaci svých produktů. ${ }^{11}$ Motorismus dal vzniknout řadě nových specializovaných živností (např. opravárenství, autoškoly, prodej pohonných hmot ${ }^{12}$ ), jiné naopak odsoudil téměř k zániku (např. podkováře).

Tématem hospodářských dějin je i hospodářský nacionalismus, který se v tak jako v jiných oblastech ekonomiky projevoval i v automobilismu, kde také našlo uplatnění heslo „svůj k svému“ ${ }^{13}$ Ostatně výroba automobilů patřila $\mathrm{k}$ hospodářské emancipaci toho kterého etnika, at již disponovalo vlastním „národním“ státem, či nikoliv. Podpora koupě automobilu „národního“ výrobce se předpokládala a také náležitě propagovala. Stejně tak mezinárodní automobilové závody znamenaly rozšíření „kolbiště“ národů. Na druhé straně přejímání vyspělejších technologií, postupů rozhodně nebylo na škodu.

Další zorný úhel, kterým byl automobilismus zkoumán, představuje právní historie. Legislativní rámec tvoří významné mantinely pro vývoj automobilismu a je zřejmé, že si automobil pozornost práva vyžádal již v závěru 19. století. Pozornosti se dočkala dosud oblast pravidel provozu na veřejných silnicích, daňových souvislostí automobilismu a pojištění odpovědnosti při provozu motorového vozidla, avšak jen se zaměřením na první polovinu 20. století. ${ }^{14}$ Druhá polovina 20. století je dosud otevřeným tématem. Hlouběji byly záležitosti evidence motorových vozidel rozpracované v publikaci Poznávací značky $v$ Čechách, na Moravě a ve Slezsku. ${ }^{15}$ Zatím jen nemálo „vlaštovek“ zachycuje legislativní pravidla a specifika v jednotlivých městech, nebot’ v oblasti silniční dopravy měla města dosti prostoru pro usměrňování jeho rozvoje. ${ }^{16}$

8 Hoffman, Petr [2010]. Poštovní autobusy (1908-1914). Dějiny státní autobusové dopravy v českých zemích a na Slovensku, díl I, Litoměřice: Vydavatelství dopravní literatury; týž [2013]. Dějiny státní autobusové dopravy $v$ Československu, díl II, Litoměřice: A. Hoffman - Vydavatelství dopravní literatury.

9 Např. Fojtík, Pavel [2006]. Garáž Kačerov 1966-2006. Praha: Dopravní podnik.

10 Jäger, Richard. [1943]. Živnost na čtyřech kolech. Praha: Český čtenář.

11 Potužníková, Marta [2015]. Audi-Werbung 1909-1965: Eine medienwissenschaftliche Analyse. Frankfurt am Main: Peter Lang.

12 Jednou z nemnohých studií k tomuto tématu je práce M. Sabola, opět však se zaměřením na Slovensko. Sabol, Miroslav [2017]. Služby motoristom, budovaní čerpacích staníc na Slovensku v počátkoch motorizácie. In. Šimko, Peter: Dejiny cestnej dopravy na Slovensku II. Žilina: Považské muzeum, s. 141-152.

13 Němec, Jan [2016]. Čeští Němci nejezdí Laurinkami, nakupují práci německých rukou. In. Na kolech do světa. Po silnicích nejen Českého ráje a Pojizeří. Z Českého ráje a Podkrkonoší- supplementum 17. Semily: SOA Litoměřice - SOkA Semily, s. 71-77.

14 Štemberk, Jan [2008]. Automobilista v zajetí reality. Vývoj pravidel silničního provozu v českých zemích v první polovině 20. století. Praha: Karolinum. Velmi stručného zpracování se dočkala i problematika dopravních přestupků. Pavlíček, Kamil - Komárek, Jindřich [2015]. Historie a vývoj silničních dopravních přestupků v právní úpravě pred vznikem Československé republiky a po jejím vzniku až do počátku České republiky. Praha: Prime Safety.

15 Zelený Filip - Feuereisel, Dalibor [2011]. Poznávací značky v Čechách, na Moravě a ve Slezsku. Chyňava: SAXI.

16 Př́́kladem může být severočeský Liberec. Zeman, Jaroslav [2013]. Krušný život motoristy. Dlažebné v meziválečném Liberci. „Automobilisto, dej ještě, dej víc!“ Fontes Nissae 14 (2): 4-14. 
Jak již bylo vzpomenuto, automobil obohatil architekturu o nový typ stavby, garáž, která se stala nezbytnou složkou nové výstavby a současně i zcela svébytnou stavbou. Jelikož bylo dlouhou dobu v rozporu s pravidly, a tedy nemyslitelné, aby automobil parkoval na veřejných prostorách, tak se garáž, at vlastní (pevná či přenosná), nebo pronajatá (včetně místa ve velkogarážích) proměnila v nutnost všedního života každého motoristy. První garáže se objevily na konci 19. století ve Vídni a zanedlouho také v Praze. Garáže se dokonce staly nedílnou součástí moderního vybavení prvotřídního hotelu. Takovým byl u nás hotel Alcron v Praze, vybudovaný podle plánů svého majitele Ing. Aloise Krofty. Nutno dodat, že nadlouho zůstal také jediným. Vybavení garáže předpokládalo stojan s pohonnými hmotami, ruční mytí a drobný servis. Stejně tak se s garáží (a také bytem pro řidiče) počítalo jako se samozřejmou součástí nových vil vznikajících v meziválečném období. Se zaměřením na meziválečné Československo a zvláště Prahu, se tematice garáží věnoval Petr Vorlík. ${ }^{17}$

Vývoj silniční sítě v kontextu automobilové dopravy stál dosud spíše na okraji badatelského zájmu. Od vydání dnes již vpravdě klasické knihy Františka Roubíka uplynulo v letošním roce 80 let. ${ }^{18}$ Samozřejmě, že v řadě i shora zmíněných prací je otázka uzpůsobování silniční sítě automobilové dopravě zmíněna, existuje též řada dílčích studií o výstavbě dálnic, ${ }^{19}$ syntetické zpracování pro automobilismus tak důležité stavby, jako je silnice, však stále chybí. Sledování silniční sítě má své styčné body i s kartografií. Automobilista potřeboval ke svým cestám mapu, aby se mohl orientovat v nových místech. Automapy tak představují specifický pramen poznávání vývoje automobilismu v zásadě pro celé 20 . století. Výklad proměn silniční sítě na pozadí automap by mohl přinášet zajímavé a interaktivní pohledy na téma silniční sítě.

Velké mezery jsou též v zachycení automobilismu v rámci urbánních dějin. Snad nejvíce by byl člověk z minulosti překvapen při průchodu ulicemi měst lemovanými nekonečnými řadami automobilů. Současný motorista stojící v dlouhých a pravidelně se opakujících dopravních zácpách naopak lamentuje nad úzkými silnicemi měst, které neumožňují rozšíření vozovky o další pruhy. Proměna tváře města je automobilem zasažena nejvíce. Teprve v nedávné době se vztah chodec - motorové vozidlo, jednoznačně vychýlený ve prospěch motoristů, začal opět vracet do rovnovážného stavu. Centra měst se postupně uzavírají pro automobilovou dopravu a přibližují se zpět nemotoristům. Tyto proměny ovlivněné společenským vnímáním motorismu si též zaslouží hlubší odbornou pozornost.

Při stručném sledování rovin motorismu jsme se pozvolna přesunuli do roviny společnosti a kultury. Automobil zvláště od meziválečného období začal vstupovat prakticky do všech oblastí života společnosti. Zvláště toto je oblast, která je v české historiografii nejméně probádaná. ${ }^{20}$ Pohledy spojující automobilismus se sociálními a kulturními dějinami se začaly v západní historiografii rozvíjet až po druhé světové válce. Souviselo to samozřejmě

17 Vorlík, Petr [2011]. Garáže. Meziválečné garáže v Čechách, zrod nového typologického druhu a proměny stavebni kultury. Praha: VCPD ČVUT.

18 Roubík, František [1938]. Silnice v Čechách a jejich vývoj. Praha: SPS.

19 Např. Lídl, Václav [2002]. Poslové zapomenuté budoucnosti, výstavba dálnic v letech 1938-1950. Praha: ŘSD; Lídl, Václav - Janda, Tomáš [2006]. Stavby, kterým doba neprála: Výstavba dálnic v letech 1938-1950 na území Čech a Moravy. Praha: ̌̌SD.

20 Uceleněji se zřetelem ke Slovensku se o podchycení širších společenských souvislostí automobilismu se zaměřením na meziválečné období pokusil Jančura, Mikuláš [2017]: Osobný automobilizmus na Slovensku $v$ rokoch 1918-1938. Košice: UPJŠ. 
s nástupem nových koncepčních přístupů a zájmem o nová témata, spojená s prríklonem $\mathrm{k}$ dějinám každodennosti, kde automobil začínal představovat důležitého hráče. S ohledem na formování konceptů kulturních dějin ${ }^{21}$ začala západoevropská historiografie zkoumat společenskou rovinu automobilismu od 60. let 20 . století.

Zájem o společenskou dimenzi automobilismu je v české historiografii relativně nového data. Pokud odhlédneme od popularizačních prací nestora české automobilové historie Adolfa Kuby, ${ }^{22}$ tak za stěžejní lze požadovat práce Jana Králíka. ${ }^{23} \mathrm{~S}$ druhou uvedenou prací jsme se přesunuli do oblasti vlivu automobilismu na občanskou společnost v rovině spolkového života a organizovaného motorismu, která má v českém prostředí tradici již od roku 1904, v německém prostředí samozřejmě delší. Při zkoumání sociální stránky automobilismu se nelze vyhnout i různým př́ístupům společenských vrstev. Více otevřené byly vyšší vrstvy, které se však současně potýkaly se silnějším konzervativismem. Zvýšeného zájmu se dosud dočkala šlechta. ${ }^{24}$ Ostatní vrstvy či skupiny obyvatelstva, jejichž zpracování bude zajisté po heuristické stránce velmi náročné, zatím zůstávají na okraji badatelského zájmu. Na přelomu 19. a 20. století se objevily také „automobilové“ paměti. ${ }^{25}$ Pod vlivem nedávných událostí v Saudské Arábii by za pozornost stál i genderový př́ístup. ${ }^{26}$ Opačný přístup, tedy vymezení zákazníků z pohledu určité - prestižní - značky, byl dosud zkoumán na vozech Bugatti. ${ }^{27}$

Společenská dimenze automobilismu se nedá zpracovat bez reflexe jeho vlivu na každodenní život i volný čas. Na jedné straně automobil jako dopravní prostředek volný čas opticky prodlužuje, na druhé ovlivňuje jeho trávení. To se promítá zvláště do oblasti cestovního ruchu, či chcete-li, autoturistiky. Autoturistika má všechny předpoklady k masové oblibě, předpoklad je jediný, mít automobil (motocykl). Autoturista se vyznačuje nezávislostí na veřejné dopravě a větším akčním rádiem. ${ }^{28}$ Autoturistika má však i své specifické požadavky (např. autokempy, motoresty). ${ }^{29}$ Volnočasová stránka automobilismu by nebyla úplná, pokud bychom nezmínili automobilový sport. Větší pozornost byla dosud věnována sportovcům a jejich strojům ${ }^{30}$ než fanouškům a fandění.

21 Burke, Petr [2011]. Co je to kulturní historie? Praha: Dokořán.

22 Např. Kuba, Adolf [1988]. Jak přišli koně pod kapotu. Praha: NADAS.

23 Králík, Jan [2001]. Století motorismu. Automobil v českých zemích. Brno: BVV; týž [2004]. Sto let klubového života 1904-2004. Brno: Ateliér Kupka.

24 Hořejš, Miloš - Křížek, Jiří, a kol. [2012]. Automobilismus a šlechta v českých zemích 1894-1945. Praha: NTM; Hořejš, Miloš - Křrižek, Jiří [2015]. Zámek s vưní benzínu. Automobily a šlechta v českých zemích do roku 1945. Praha: Mladá fronta.

25 Bierbaum, Otto Julius [1903]. Eine empfindsame Reise im Automobil. Berlin: Bard.

26 Lehce naznačený v pracích: Pachmanová, Martina, Sen o automobilu. Moderní obraz ženy za volantem a prvorepubliková reklama. Dostupné z: <www.zenyvumeni.cz/index.php?id=94>; Klusáčková, Lucie [2016]. Fenomén automobilismu a ženy za první republiky. Bak. práce, MU, FF. Brno.

27 Garnier, Pat - Janoušek, Ivo - Kožíšek, Petr [2002]. Automobily Bugatti v českých zemích. Praha: NTM.

28 Pro meziválečné období srovnej: Štemberk, Jan [2009]. Fenomén cestovního ruchu. Možnosti a limity cestovního ruchu v meziválečném Československu. Pelhřimov - Praha: Nová tiskárna Pelhřimov - VŠO v Praze. Pro dobu 40. let 20. století, kdy byla úloha autoturistiky s ohledem na situaci okrajová, srovnej: Jakubec, Ivan - Štemberk, Jan [2018]. Fenomén cestovního ruchu. Cestovní ruch pod dohledem třetí říše. Praha (v tisku).

29 Štemberk, Jan [2017]. Pěšky, na lyžích, na kole, lodi či autem. K dějinám československé turistiky v letech 1945-1968. Pelhřimov: Nová tiskárna.

30 Skořepa, Miloš [1969]. Mistři za volantem. Kniha o automobilových závodnících. Praha: Olympia; Hořejš, Miloš, a kol. [2014]. Jiří Kristián Lobkowicz, aristokrat s duší závodníka. Kapitoly z dějin české aristokracie a automobilismu. Praha: Mladá fronta - NTM. 
Na motorismus začala reagovat i kultura. Automobil pronikl do divadla, poezie, ${ }^{31}$ prózy, výtvarného umění, hudby a později i do filmu, ale také do rozhlasu a televize. Ladné křivky automobilu se staly novým objektem pro estetično a krásno. Nejnověji nákladní pronikl automobil až na prkna naší první scény v modernizovaném pojetí Fausta.

Automobil se dostal do zorného pole divadelních her již před první světovou válkou ${ }^{32}$ a tento zájem pokračoval i po ní. ${ }^{33}$ Postupně se také stal námětem pro dětská představení s výchovně-vzdělávacím aspektem. ${ }^{34}$ Nové tisíciletí rovněž přineslo několik českých „automobilových" her. ${ }^{35}$ Ani v zahraniční autoři (jako I. Bergman, E. A. Longen, T. Wilder) ${ }^{36}$ automobil neopomenuli, většinou se však vztah umění a automobilu (a techniky) omezuje na futuristy v čele s Eugènem Ionesco. ${ }^{37}$ Ani oblast hudby nezůstala automobilu ušetřena. ${ }^{38} \mathrm{~V}$ nedávné době vyšla rovněž skvělá studie o vztahu automobilu a hudby. ${ }^{39}$ Čeští umělci se pak soustředili na zachycení automobilu jako součásti všedního života, ${ }^{40}$ viděli motocykl ${ }^{41}$ a automobil či autobus ${ }^{42}$ jako svébytnou formu. ${ }^{43}$ Speciální př́pad uměleckého ztvárnění událostí útěku občanů NDR do SRN představuje socha trabanta na nohou (Trabant) Davida Černého z roku 1989. Z hlediska estetického připomeňme alespoň Tatru 77 Hanse Ledwinky. Je potěšitelné, že na českých vysokých školách vznikají kvalifikační práce s problematikou automobilismu, jež je pojímána $\mathrm{z}$ nejrůznějších pohledů (ekonomicky, technicky, biograficky nebo inovativními př́stupy). ${ }^{44}$

Stranou nemůže zůstat ani symbolika. Automobil se stal symbolem rychlosti, společenského postavení, úspěchu i životního stylu. Symbolika se proměňovala i s ohledem na politické režimy. Symbolem nacistické politiky se stal lidový automobil, na který si může našetřit každý, i dělník. Socialistická ideologie automobil odmítala, alespoň ve svých

31 Automobil se dostal i do názvu básnické sbírky. Hruška, Petr [2007]. Auta vjiždějí do lodí. Brno: Host. Lze zmínit rovněž báseň Ivana Blatného: Masarykův okruh.

32 Kraatz, Kurt [1906]. Automobilista. Žert ve třech jednáních. Praha: M. Knapp.

33 Nový, A. J. [? po 1926]. „Revoluce v domácnosti“ (Made in Czechoslovakia). Veselohra o třech jednáních. Praha.

34 Kašpárek v Americe čili O tom, čeho je se stříci našim dětem na ulici [1923]. In. Driml, Karel: Kašpárkovy zdravotnické táčky. Kašpárkovy výstupy pro loutkové, maňáskové, bramborové a dětské divadélko. Choceň; Nešvera, R. [1929]. Automobilová princezna. Loutková veselohra o třech jednáních. Praha: Dr. J. Veselý; Karas, J. F. [1930]. Automobilový princ. Společenská hra s veselým koncem o třech jednáních. Praha: Fr. Švejda; Trampoty automobilisty [1933]. In. Balák, Karel. Veselá dětská beseda. Básně, recitace, písně a sceny pro veselé dětské besedy. 2. díl. Praha, s. 37-39 a Veselí automobilisté [1940], tamtéž. 3. díl, s. 29-31; Skořepa, Zdeněk [1962]. Blues porouchaného automobilu. In. Hř́íky nevážné i závažné. Loutkové hry pro velké diváky. Praha, s. 19-21.

35 Drábek, David [2002]. Embryo čili Automobily východních Čech. Horor v̌̌edního dne. Dvě dějství + černá skř́inka. B.m.; Branald, Adolf - Balaš, Radek [2009]. Dědeček automobil (muzikálové leporelo s hudbou George Gershwina). Mladá Boleslav.

36 Bergman, Ingmar - Longen, Emil Artur - Wilder, Thornton [b.d.]. Radosti majitele automobilu. Mladá Boleslav.

37 Ionesco Eugène [1961]. Der Automobilsalon. In. Dreizehn europäische Hörspiele. München: Piper, s. 113-118.

38 Postava Spejbla zpívala milostný song, kde automobil hrál významnou roli: „Abych si Tvé srdce dobyl, koupím já ti automobil!“ Večerní valčíková serenáda [1929]. Praha.

39 Poláková, Markéta - Šederová Purschová, Adéla [2012]. Auto-pop: Vášnivé a osudové spojení automobilu a populární hudby. Anthropologia integra 3 (2): 45-66.

40 Duša, Ferdiš [1923]. Ulice večer, dřevoryt.

41 Švec, Otakar [1923]. Sluneční paprsek (Motocyklista), bronz; Lhoták, Karel [1942]. Motocykl se zeleným prívěsným vozíkem, olej.

42 Karoušek, Ladislav [1958]. Večerní autobus, plátno.

43 Sudek, Karel [1932]. Kov a sklo, fotografie.

44 Např. Jančařík, Tomáš [2007]. Esej o automobilismu s přihlédnutím ke konceptu „jeveni“ u Adolfa Portmanna. Geneze, morfologie a význam automobilové formy z hlediska etologie. Bak. práce, FHS UK. Praha. 
počátcích, jako pozůstatek buržoazních časů, naopak motocykl byl však vnímán jako „proletářský“ dopravní prostř̀edek.

Automobil tedy vyjadřoval individualismus, svobodu, opojení rychlostí, výraz úspěšného profesního a sociálního postavení (statusu) ve společnosti (at již získaného rodinným majetkem či profesí). K tomu po první světové válce přibyla ještě další dimenze, a to demokratizace, k níž došlo v souvislosti s vyšší dostupností (v porovnání se situací před rokem 1914) automobilu pro spotřebitele. Od „pouze“ dopravního prostředku spojeného s výkonem profese, se automobil stal i sportovním náčiním, sportem, typem trávení volného času (autoturistika, mototuristika) a symbolem konzumní společnosti. Současně se automobil stal jakými „multiplikátorem“ pro národní hospodářství a společnost, jak tuto funkci plnila železnice v 19. století. Závislost na automobilové produkci je ve vyspělých ekonomikách enormní a každé zaváhání ekonomického cyklu nese s sebou doslova dominový efekt nejen samotné výroby automobilů a dodavatelů, ale i dalších odvětví hospodářství.

Komplexní zkoumání fenoménu automobilismu vyžaduje nejen různorodý tým $\mathrm{z}$ hlediska profesního zařazení a víceleté badatelské úsilí. Před časem se o to pokusili na Pedagogické fakultě Univerzity Palackého v Olomouci s internetovým výsledkem „Člověk-Auto-Encyklopedie“ (on-line). Jedná se o chvályhodný počin s otevřeným závěrem (stále vznikají nová hesla, resp. Heslář odkazuje na jejich pozdější realizaci) a možná až přiliš velkými ambicemi z hlediska obsažnosti (celosvětový a „všeobsažný“ záběr). ${ }^{45}$ Nejnověji se realizuje poněkud sevřenější a také reálněji zpracovatelný projekt pod vedením Univerzity Karlovy (FHS) za účasti Národního technického muzea v Praze a Technického muzea v Brně pod názvem „České století motorismu“, zaměřený na představení posledních sto let vývoje automobilismu a motorismu v českých zemích, respektive Československu v širokém společenském (kulturním, politickém, technickém) kontextu. Výsledkem projektu budou publikace, studia a články v periodikách, výstavy a interaktivní mapy.

Ivan Jakubec $\left({ }^{\star} 1960\right)$ působí na Ústavu hospodárských a sociálních dějin Filozofické fakulty Univerzity Karlovy. Odborně se zabývá moderními hospodářskými dějinami 19. až 20. století, dějinami techniky, dopravy a infrastruktury.

$45<$ https://is.muni.cz/do/sci/UAntrBiol/el/clovek-auto/index.html> [30. 6. 2018]. 